\title{
Muslim views on other religions: With special reference to Buddhism
}

\begin{tabular}{|c|c|}
\hline $\begin{array}{l}\text { Authors: } \\
\text { Jaffary Awang } \\
\text { Ahmad F. Ram } \\
\text { Zaizul A. Rahm }\end{array}$ & $\begin{array}{l}\mathrm{i}^{3} \text { (1) } \\
\operatorname{an}^{1} \text { (1) }\end{array}$ \\
\hline $\begin{array}{l}\text { Affiliations: } \\
{ }^{1} \text { Research Cen } \\
\text { Theology and } \\
\text { Faculty of Islar } \\
\text { National Unive } \\
\text { Malaysia, Ban } \\
\text { Malaysia }\end{array}$ & $\begin{array}{l}\text { tre for } \\
\text { Philosophy, } \\
\text { nic Studies, } \\
\text { rsity of } \\
\text { ji, Selangor, }\end{array}$ \\
\hline $\begin{array}{l}{ }^{2} \text { Department } \\
\text { and Citizenshi } \\
\text { Human Scienc } \\
\text { Education Uni } \\
\text { Malim, Malay }\end{array}$ & $\begin{array}{l}\text { f Social Studies } \\
\text {, Faculty of } \\
\text { es, Sultan Idris } \\
\text { /ersity, Tanjong } \\
\text { ia }\end{array}$ \\
\hline $\begin{array}{l}{ }^{3} \text { Institute of Is } \\
\text { National Unive } \\
\text { Malaysia, Ban }\end{array}$ & $\begin{array}{l}\text { am Hadhari, } \\
\text { rsity of } \\
\text { i, Malaysia }\end{array}$ \\
\hline $\begin{array}{l}\text { Correspondin } \\
\text { Ahmad F. Ram } \\
\text { ahmadfaizudd } \\
\text { com }\end{array}$ & $\begin{array}{l}\text { author: } \\
\text { in@outlook. }\end{array}$ \\
\hline $\begin{array}{l}\text { Dates: } \\
\text { Received: } 08 \\
\text { Accepted: } 22 \\
\text { Published: } 27\end{array}$ & $\begin{array}{l}\text { Mar. } 2021 \\
\text { May } 2021 \\
\text { Aug. } 2021\end{array}$ \\
\hline $\begin{array}{l}\text { How to cite th } \\
\text { Awang, J., Ran } \\
\text { Rahman, Z., } 2 \\
\text { views on othe } \\
\text { With special r } \\
\text { Buddhism', HT } \\
\text { Studies/Theolc } \\
77(4), \text { a6608. } \\
\text { org/10.4102/r }\end{array}$ & $\begin{array}{l}\text { is article: } \\
\text { li, A.F., \& } \\
21, \text { 'Muslim } \\
\text { religions: } \\
\text { ference to } \\
\text { S Teologiese } \\
\text { gical Studies } \\
\text { tttps://doi. } \\
\text { ts.v77i4.6608 }\end{array}$ \\
\hline $\begin{array}{l}\text { Copyright: } \\
\text { (C) 2021. The A } \\
\text { Licensee: AOS } \\
\text { is licensed unc } \\
\text { Creative Comr } \\
\text { Attribution Lic }\end{array}$ & $\begin{array}{l}\text { uthors. } \\
\text { S. This work } \\
\text { er the } \\
\text { nons } \\
\text { ense. }\end{array}$ \\
\hline Read online: & \\
\hline 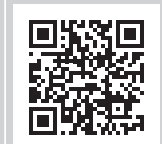 & $\begin{array}{l}\text { Scan this QR } \\
\text { code with your } \\
\text { smart phone or } \\
\text { mobile device } \\
\text { to read online. }\end{array}$ \\
\hline
\end{tabular}

The literature analysing Muslim perspective towards other religions is now quite extensive. However, when it comes to Muslim's perspective towards Buddhism, the scholarship lags far behind. This article aimed to identify the Muslim views on Buddhism from a theological and philosophical framework. The Muslim views have a different category, on categorising Buddhism, the status of Buddha as a Prophet, and Buddhist as the People of the Book. Each view provides a different framework of Muslim perspective towards Buddhism. From the theological view, one of the outlook is tolerance. Due to the rejection of Buddhist doctrine by most Muslim theologians, Muslims apply tolerance, which is subject to religious freedom stand on, 'firm in principle, tolerant in attitude'. Tolerance encourages Muslims to adhere to the principles of truth, but does not erode the respect for other religion. While from a philosophical view, it considered Buddhism as a religion from God, as well as other religions. Thus, some Muslim inclusivists and pluralists recognise Buddhism. This research is qualitative. The method used in this research is descriptive-analytic, emphasising content analysis of the data from various books and articles covering Muslim view on Buddhism and the patterns of relations between Islam and Buddhism. Studies suggest the understanding of each framework to encourage Muslims to improve comprehensive interreligious dialogue with Buddhists.

Contribution: Religious tolerance, inclusivism, and pluralism is a panacea to inordinate and incessant religious conflict, if given its proper place in Malaysia, it will breed harmony and peace in the society. This work would be of immense benefit to interfaith scholars and religious leaders across all strata of discipline.

Keywords: Islam and Buddhism; interfaith relation; interreligious dialogue; religious pluralism; religious tolerance.

\section{Introduction}

The approach to interfaith relations built on various contexts, historically, theologically and philosophically, makes the discipline of interfaith relation between people relevant in facing the challenges of diversity. The diversity comprising different traditions, races, and religions as a testament to the greatness of Allah, and the wisdom of human beings to know each other, leads to building good relationships amongst people in daily life. Speaking about the issue of interreligious relations that usually begins with interaction and dialogue, formally or informally. Dialogue as explained by Cheetham et al. (2013:1) is one of the aspects of rational relations between believers, in addition to other issues such as consensus between the majority and minority communities, the issue of embracing more than one religion, cooperation, the position of religion in public domination, initiatives to build harmony, and so on. All these issues are related to the question: how perceptions and understanding of a religion change according to the adherents of the religion and the others. Thus, in the context of the study of religions in the 21st century, emphasis should be given to the context of intra-faith and inter-faith, based on a specific framework that has been proposed by religious scholars who propound the discipline of interreligious relations.

In the context of the Southeast Asian region, Islam and Buddhism are the most widely practiced religions, but relationship between the two religions has not been given ample attention (Azhar et al. 2013:12; Reis Habito 2010:233), compared to Muslim relations with adherents of other religions which has been highlighted in many scholarly studies. Based on the historical records, earliest interactions between Muslims and Buddhists took place in the middle of the 7th century AD, and flourished in Central Asia until the 10th century AD (Beckwith 1979:297; Hussain \& Ramli 2017:204; Maclean 1993:196; Selim 2011:179; Yoeli-Tlalim 2016:4; Yusuf 2013:361). Either the 
lack of attention is because of theological factors that are difficult to compare, or vague historical factors (Yusuf 2010b:177). Muslims and Buddhists today are however, part of a religious community that is connected with each other and living a harmonious life, especially in the context of the region. Unfortunately, the failure to understand and the absence of an element of tolerance between believers have led to a clash between both the religious communities. For example, the oppression of Muslim minorities in Buddhistmajority countries based on the prejudice that Muslims want to control Buddhist-owned countries (Gravers 2015:2; Stewart 2014:241). This narrative was further compounded by the historical sentiment that Muslims once plundered Buddhist countries (Yusuf 2018:505). Based on this portrayal, Muslims are considered as a threat to the survival of the religion, culture, economy, and country amongst Buddhists (Crouch 2016:34; Gravers 2015:2; Klinken \& Aung 2017:2; Stewart 2014:241), although this sentiment is baseless. The phenomenon of prejudice against the Muslim community obliquely proves the element of Islamophobia amongst Buddhists (Osman 2017:21, 2019:18; Ramli, Awang \& Rahman 2020b:89; Sharma, Ghafoor \& Gogineni 2019:95). What is more, such accusations are contrary to Islamic teachings that emphasise peace and harmony. Even in times of war, Islam demands its followers to adhere to strict principles, such as, preserving the house of worship and giving full protection to the old people, women, and children. Therefore, the importance of identifying and understanding the principles of Islamic teachings that guide Muslims in shaping their views and attitudes towards followers of other religions, including Buddhists. Through this understanding, Buddhists will see Muslims in a more positive view as well as help in creation of spaces for the implementation of a more comprehensive Muslim-Buddhist dialogue.

\section{Buddhism category}

According to Hosein (1976:53), non-theism does not connote atheism (denial of the existence of God), rather it acknowledges the existence of any Deity but is unconcerned about it. Buddha was once asked by his disciple whether God existed or not. He did not say anything. When pressed, he responded by comparing himself to a person suffering from stomach ache. Would he be more concerned about pain relief or with studying the physician's prescription? Then Buddha stressed, 'It is neither my nor your concern to determine whether or not there is a God - our mission is to remove the suffering of the world.' Hence, providing the doctrine of Dhamma (Dharma) or the 'Impersonal Law', in place of God (see, Reza Shah-Kazemi 2010:128, who agrees with Buddha's non-theistic doctrine). In other words, it demonstrates that there is no personal divinity in Buddhism who plays the roles of Creator, Revealer, and Judge. But to claim that Buddha's doctrine is 'atheistic' would be to attribute to him an explicit denial and negation of the Absolute - which can be found nowhere in his teachings. According to Rahmat (1984:290), although Buddha is not talking about the concept of divinity, it does not mean that
Buddha denies the existence of God. This is because the community's environment inhabited by Buddha has its concept of divinity, therefore Buddha does not interfere with the theology that is already rooted. Thus, Buddha can be considered a figure who purifies the teachings of Hinduism, just as Jesus purified the teachings of the Jews. So, finding a lack of Hindu teachings that do not allow one to achieve nirvana, Buddha offers a specific way to achieve that goal (Basri 2009:105; Rahmat 1984:290).

Instead of religion, some Muslims regard Buddhism as a philosophy since Buddha's original teaching never teaches about God. If it is a religion, it should consist of the concept of faith in a supreme power that protects all beings, determines human destiny, and accepts God-provisions over humans. Buddha himself can neither be considered as a Prophet nor a founder of any religion. Buddha did not receive revelation, and he thought only about the life that he experienced. He severed his ties with the religious way of life of his Hindu community who worshipped countless Goddesses. In facing the questions of life, Buddha sought a solution until it was completed without emphasising the concept of divinity. This can be solved by training the mind to the highest level. However, after his death, his followers felt it was a loophole in his teachings because it did not emphasise the concept of divinity. Eventually, they changed their teachings by positioning Buddha equally to God, contrary to Buddhism's original teachings (Basri 2009:105; Syalaby 1970:180).

\section{Buddha as a prophet}

According to some Muslim scholars, the foundation of Buddha prophethood was rooted in a verse in the Qur'an that stated about 'unmentioned prophets' (Q 4:164, 40:78) in general. However, some Muslim scholars contextualising several terms in the Qur'an, which is Șābi'īn, Dhu al-Kifl and at-Tīn refer to Buddha (Ramli et al. 2020a:61). These versions were related by Al-Maqdisi (2004, vol. 3:139), followed by theologians al-Biruni (d. 1048 CE) and al-Shahrastani (d. 1153 CE) with a term Șābi'īn in the Qur'an that refers to the followers of a prophet in India named Yudhasaf, as well Budhasaf and Budhasab (Ramli et al. 2020a:59; Tabataba'i 1997, vol. 1:194; Tabrizi 2012:461). According to Vaziri (2012:44), Sadiqi (2008:227), and Smith (1981:6), the words Yudhasaf was derived from Persian Bodisaf which translated from the word Bodhisattva in Sanskrit. Al-Shahrastani (1992:712) on the other hand, although did not state the position of Buddha directly whether a prophet or not, however, in his works, he compared Buddha with Khadir (Khidrr), a legendary Islamic saint (and a prophet) whose existence is taken for granted by Muslims. Instead of word Șābi'īn, modern Muslim theologians like Hamid Abd alQadir (1895-1966) (Ramli et al. 2020a:61) and supported by Muhammad Hamidullah (1908-2002), refer to Buddha as Prophet Dhu al-Kifl in the Qur'an (Ramli et al. 2018:4; Yusuf 2010b:182). In his work Buddha al-Akbar Hayatuhu wa Falsafatuh, Hamid Abd al-Qadir (Ramli et al. 2018:4) proposes that the Qur'anic mention of the fig tree in chapter 95 refers 
to Buddha as well, since he attained enlightenment at the foot of one. However, the proposition came together with the term 'Dhu al-Kifl' which is stated twice in the Qur' an (Q $21: 85 ; 38: 48)$.

Hamid 'Abd al-Qadir together with Maulana Vidyarthi (2020) justified his position based on the word kifli, which means 'someone from Kifl' (Berzin 1994; Obuse 2010:216; Ramli et al. 2020a:61; Schmidt-Leukel 2010:358; Yusuf 2013:363). The word kifl is the Arabicised form of 'Kapila', which is a contraction of 'Kapilavastu', the birthplace of Buddha, hence he is named 'Dhu al-Kifl' (Berzin 1994; Obuse 2010:216; Schmidt-Leukel 2010:358; Vidyarthi 2020:5; Yusuf 2013:363). Instead of the word kifli, the word of tin referred by Muhammad Hamidullah (1974:27) and later supported by Imtiyaz Yusuf (2013:363) is used to describe a Bodhi tree where Buddha meditated and attained the enlightenment (nirvana). Interestingly, this claim was justified by modern Muslim exegesis al-Qasimi (2003, vol. 9:502), where the chapter of at-Tīn in the Qur'an is symbolic to Buddha. This view led into categorising the Buddhists as the followers of the pseudo-Prophets identical to ahl al-Kitāb (the People of the Book) (Sirry 2012:181). Therefore, as Buddha is referred by several terms in Qur'an most of the Muslims instead of speculating accept him as an 'unmentioned prophet', as stated in the Qur' an literally (Rahmat 1984:290).

\section{Buddhists as the people of the book}

The concept of the People of the Book (Ahl al-Kitab) was rooted in the Qur'an on engaging with other religion $(Q$ 3:64). 'The People of the Book' is a literal translation of the Qur' anic term Ahl al-Kitāb, which is used to refer to both Jews and Christians as believers in a revealed book - either collectively or separately. In general, there are two approaches to the People of the Book in the Qur'anic text. On the one hand, it mentions the People of the Book numerous times and defines itself as 'confirming' (Q 3:4-5; 5:46) the earlier revelations. Besides, the Qur'an provides an opportunity to establish the best relationship with the People of the Book by allowing Muslim men to marry their women, and to eat their food and the animals that they sacrifice, as stated:

This day are (all) things good and pure made lawful unto you. The food of the People of the Book is lawful unto you and yours is lawful unto them. (Lawful unto you in marriage) are (not only) chaste women who are believers, but chaste women among the People of the Book, revealed before your time. (Q 5:5)

And:

Those who believe (in the Qur'an) and those who follow the Jewish (Scriptures) and the Christians and the Sabians, any who believe in Allah and the Last Day and work righteousness, shall have their reward with their Lord; on them shall be no fear, nor shall they grieve. (Q 2:62) (Çoruh 2012:505)

However, other views of classical Muslim scholars insist that any community which one supposes to possess scripture can be regarded as People of the Book - for example, Zoroastrians. This argument, according to al-Mawdudi, expanded by some modern Muslim scholars, to the point where the adherents of Buddhism also can be regarded as People of the Book. For example, Ibn Kathir informs us that Abu Thawr Ibrahim b. Khalid al-Kalb (d. 860), the loyal follower of Shafi'e and Ahmad b. Hanbal, states that the meat slaughtered by the Zoroastrians may lawfully be consumed and that Muslims are permitted to marry their women (Wahyudi 1997:30).

The views of Buddhists as the 'People of the Book' are supported by some modern Muslim exegetes as Rashid Rida in his Tafsīr al-Manār. He explains that the concept of Ahl Kitab not limited to the Jews and Christians, but also includes Buddhists, along with the Șābi'în, Zoroastrians, Hindus and Confucianists. He justifies that the Saābi'în and Zoroastrians are mentioned in the Qur'an but not the Brahmans (Hindus), Buddhists, or Confucians because the Șābi'în and Zoroastrians were known to the Arabs of Iraq and Bahrain. The earlier religions were located far away from Arab countries (i.e., Hinduism and Buddhism originated from India and Confucianism from China). The Arabs themselves had not yet travelled to India, Japan, or China. In the interest of avoiding a strange statement (ighrab), this verse does not mention those religions of which the Arabs were not yet aware (Wahyudi 1997:30).

\section{Muslim approach towards interfaith dialogue}

Most Muslims and Buddhists have come a long way from the historical legacy of non-recognition by Muslims or marginalisation by Buddhists in Malaysia. They now recognise that communication between them is critical to the preservation of global peace. For example, Chandra Muzaffar, initiates a dialogue with Sivarasa in discussing the challenges of globalisation towards the Muslim and Buddhist community in Asia (Sivarasa \& Muzaffar 1999:16). Osman Bakar, a prominent Muslim scholar, together with Imtiyaz Yusuf and Reza Shah-Kazemi, also wrote in support of such dialogue. It was characterised by an emphasis on philosophical and mysticism dimensions that acknowledges differences and similarities. The initiative for MuslimBuddhist dialogue is also expressed through their collaboration at the institution level between Malaysian Chinese Muslim Association (MACMA), Islamic Information and Services Foundation (IISD), Hidayah Centre, and Centre for Civilizational Dialogue. Apart from programmes in the form of formal dialogue, the Muslim community also welcomes the organisation of the 'Mid-Autumn Festival Lantern Program' (Soka Gakkai Malaysia 2014), celebrations such as open houses, daily interactions as neighbours and community, and in matters involving common interests such as buying and selling, etc. What is more interesting, on February, 2018, the organisers of the 'Let's read the Qur'an campaign', invited the highest leader of Malaysian Buddhism, Venerable K. Sri Dhammaratana to join the Muslim event (The Star 2018). Similarly, in the aspect of social work, the Muslim community expresses togetherness through involvement in health campaigns, such as the Cigarette Quit 
Campaign (Yong et al. 2009:1027). Meanwhile, in the aspect of diplomacy, the positive attitude of Muslims is manifested through their assurance of the right to freedom of religion and the construction of houses of worship of Buddhists (Yusoff Ismail 2010:326).

As far as Muslims are concerned, the demand for dialogue has culminated in a new era in the history of dealing with religious problems such as inter-religious interactions and co-existence with the world's multi-religious societies today. With this current recent phenomenon in the face of the Muslim world, how do they react to these new realities that could give rise to some sensitive repercussions on the very bottom of their faith? Having stated the context of the whole scenario, what the Muslims are heading towards is call for interfaith dialogue. There are verses from the Qur'an that proclaim the call of believers to religious discourse. The concept of universalism, which is the heart of the Islamic message, could not be realised without genuine openness to others. To send our divine teachings, it is ridiculous to exclude ourselves from the rest of the world's religions. Allah says in the al-Qur'an: 'We sent thee not, but as a Mercy for all creatures' (Q 17:107). In Islam, Muslims are told to deal with non-Muslims kindly and justly. Prophet Muhammad once said as mentioned in his traditions:

Whosoever is cruel on dhimmi or curtails his right or burdens him more than he can endure, or take anything from him against his free will, I shall myself be a complainant against on the Day of Judgment. (Ahmed El-Wakil 2019:2)

The Qur'an prescribed how Muslims should take into account and be able to foresee the different backgrounds of human beings and teach its followers ways and means to deal with this diverse and mixed society. Allah says in the al-Qur'an:

O mankind! We created you from a single (pair) of a male and a female, and made you into nations and tribes, that ye may know each other (not that ye may despise each other). Verily the most honoured of you in the sight of Allah is (he who is) the most righteous of you. And Allah has full knowledge and is well acquainted (with all things). (Q 49:13)

The question of whether to participate in interfaith dialogue continues to divide Muslim scholars. Do Muslims have a universal and clear formula for dealing with the issues and consequences that affect the Muslim community if they want to participate in dialogue? What are the best techniques and methods that Muslims can provide to the world's population so that not only the Muslim Ummah benefits, but the whole world is shaped for a brighter future? Despite the overwhelming obstacles that this new phenomenon presents, Muslims now have a clear guide to help them carry out their task to the rest of the world. It is all about monotheism and acknowledging Allah's divinity and lordship. Certain sections of the Islamic authorities are eager and willing to engage in this type of religious discourse without showing any signs of trepidation. Some Islamic nations, organisations, and clerics support the change at this time, but with reservations. They are usually extremely cautious in their approach and establish certain methodological requirements before engaging in any theological discourse. Scholars like Osman Bakar, Imtiyaz Yusuf, are well-known figures who supported the idea for interfaith dialogue, but have outlined certain pre-conditions, approaches and methodologies.

\section{Tolerance}

In the Islamic view, Muslims have their perspective in defining the concept of tolerance. The word tolerance or tasamuh (Arabic), according to Abdullah (2007:213), refers to the welcoming and fostering of human diversity as one's of Allah wisdom' in creating mankind. In the Qur'an, Allah states: 'And if your Lord had willed, He could have made mankind one community; but they will not cease to differ. Except whom your Lord has given mercy, and for that $\mathrm{He}$ created them. But the word of your Lord is to be fulfilled that, "I will surely fill Hell with jinn and men all together"'. (Q 11:118-119). This verse shows that when human society was made in a large community, the differences and disagreement of belief cannot be avoided. Regardless of the differences, the Qur'an also teaches us to honour and respect others under the spirit of humanity and a human created by Allah (Abdullah 2007:220).

Bakar (2013:91) discusses the tolerance in the Qur'an by relating it with three verses, which promote the principle of 'no compulsion in religion' -'Let there be no compulsion in religion. Truth stands out clear from Error; whoever rejects Evil and believes in Allah hath grasped the most trustworthy hand-hold that never breaks. And Allah heareth and knoweth all things'. (Q 2:256); 'the three-invitation methodology to Islam':

Invite (all) to the way of thy Lord with wisdom and beautiful preaching; and argue with them in ways that are best and most gracious: for thy Lord: knoweth, best who have strayed from His Path, and who receive guidance. (Q 16:125)

And 'the affirmation of faith' - 'To you be your Way, and to me mine'. (Q109:6). The Qur'an's principle of 'no compulsion in religion' explicitly forbids Muslims from forcing or compelling non-Muslims to convert to Islam, because conversion should be voluntary and willing; their conversion to Islam must rely entirely on their wills and faiths in Islamic traditions and practices, as well as Islamic teachings in general. While under the principle of 'three invitation methodology to Islam', the Qur'an instructs Muslims to use three approaches which include: wisdom, good advice, and good debate (Ramli \& Awang 2016:32). If these three approaches of inviting any non-Muslim to Islam does not work, Muslims must adhere to remain with the principle of 'affirmation of faith'. This means that Muslims who have invited any non-Muslim to embrace or accept Islam and they have failed to convince him, they should allow him to practice his religion of choice. (Ramli \& Awang 2016:32). 
While Khambali et al. (2019:131) described tolerance, as to give and take, not only expecting 'one party to give and the other to receive'. Alhashmi, Bakali and Baroud (2020:13) refers to tolerance as 'to that which is easy, free from knots, easy-going, and generous'. Tolerance also refers to an attitude of openness to listen to different views, functioning bilaterally, that is, delivering and accepting views without affecting each other's religious beliefs within a mutual understanding, and not merely religious pluralism (Sirry 2009:431). Thus, in Islam, tolerance does not mean to be merely accepting to the point of stressing things that are contrary to the teachings of Islam. Tolerance in Islamic view is subject to religious freedom stands on, 'firm in principle, tolerant in attitude'. (Ghazali 2016:28; Khambali et al. 2019:131).

Tolerance in Islam urges its followers to hold on to the principle of truth on the basis and principles of tawhid (Qomaruzzaman \& Busro 2019:230), without disregarding respect towards non-Muslims. Islam highly upholds tolerance as part of the approach to dealing with others (Jome, Ganjvar \& Sarmadi 2020:5). For example, al-Qur'an (Q 60:8), educates us to be fair and be kind to others who differ in faith, as part of the most important condition that leads to the notion of tolerance. Islam only allows tolerance on matters that do not violate the rules and principles of Islamic teachings. Islamic tolerance is within the scope of restoring the essence of individual freedom so that his life is more civilised and moral, without corrupting the principle of Islam and at the same time not neglecting the existence of other religions (Rahman \& Khambali 2013:83). On this basis, Muslims perceived that Buddhism belongs to the group of idiolatry religions. This distinguishes Buddhism from the monotheism religion as the religion of the People of the Book. As for the teachings of Buddhism, Muslims see no common doctrine. Most Muslim theologians categorise them as polytheists (Yusuf 2010a:114). So, based on Islamic theology, tolerance plays a role in shaping the Muslim view on Buddhism.

\section{Inclusivism}

Inclusivism comes from the understanding of inclusiveness, which refers to the doctrine that all religions have their path to salvation, and that path is recognised (Safehian 2013:3853). According to Runzo (2010:66) and Van Eck (2009:5), although inclusivism recognises the paths in other religions, it only includes some of the truth in the religion practiced. This is because adherents of inclusivism still put the priority on the religion that has the truth perfectly. The inclusive policy is rooted in religious philosophy in evaluating the theological response among religious people (Kroesbergen 2020:6). Among Muslims, the inclusive paradigm is also recognised with justification for Islamic theology and philosophy (Ali 2018; Bakar 2012:444; Çakmak 2016:469; Hanafi 2017:36; Hassan 2009:109; Tasman 2017:143). For the Muslims inclusivist, they remained with the view Islam is the truest religion, however, Buddhism also contains part of the truth. The recognition of part of the truth is essential to sustain harmony among the nation
(Habibi 2017:36). It does not mean allowing other doctrines or teachings of Buddhism to mix with Islam, except to manifest with the universality of Islam, under the concept rahmatan lil âlamin (as a mercy to the worlds). According to some Muslim views, this inclusive paradigm is more compatible in the context of facing the challenges of religious diversity and thought. This also coincides with fitrah and sunnatullah in the Qur'an:

And among His Signs is the creation of the heavens and the earth, and the variations in your languages and your colours: verily in that are Signs for those who know. (Q 30:22)

Which makes man in a variety of views, although God has the power to make man in one character and kind:

If Allah had so willed, He would have made you a single people, but (His plan is) to test you in what He hath given you: so strive as in a race in all virtues. The goal of you all is to Allah; it is $\mathrm{He}$ that will show you the truth of the matters in which ye dispute. (Q 5:48) (Habibi 2017:36)

Cultural diversity should be seen as something positive by Muslims, without prejudice to others. In fact, Muslims should take advantage of the atmosphere of diversity to find mutual understanding. Thus, it will raise awareness in building relationships between believers, without diminishing the slightest confidence of a Muslim. This awareness is built on the principles of tolerance, freedom, openness, fairness, justice, and honesty. Inclusivist Muslims also recognise the values of truth in the teachings of religion. This is based on the mission of the Prophets and Messengers to each different race and different nation. For example, the law that was revealed to the people of the Prophet Jesus in contrast to the Sharia revealed to Prophet Musa, and likewise among the Prophets and Messengers others. Despite the different requirements, the earliest basis of teaching for each religion is monotheism, only after the passage of time, the teachings of religions other than Islam are distorted.

In the inclusive pattern, the origin of Buddhist teachings is the same as the teachings of monotheistic religions. Thus, Buddhists can still be classified as People of the Book as Judaism and Christianity as recorded in the first Muslim meet on Buddhist (Elverskog 2010:49; Yusuf 2010a:130; Reza Shah-Kazemi 2010:xiv; Obuse 2015:303). This is based on the inclusive pattern and is significant because there are several teachings in Buddhism; the concept is similar to the teachings of Islam, for example, in the practice of Sufism. This is contrary to the view of the majority of Muslim theologians who categorise Buddhists as polytheists because the basis of such teachings does not emphasise divinity. To inclusivist Muslims, they agree with the view of some Islamic scholars who recognise the position of Buddha as the Prophet sent by Allah as the other Prophets. Only the name of Buddha is not mentioned directly in the Qur'an, like the other Prophets in the historical record. Thus, an inclusivist Muslim will be seen open in establishing relations between believers because they still accept and recognise some truth elements in other religions, including Buddhism. 


\section{Religious pluralism}

The paradigm of religious pluralism recognises the diversity of religions that exist as part of God's rules that need to be celebrated. This means that every religion is equal (Asadu, Diara \& Asogwa 2020:2), contains the ultimate true (Thiselton 2008:187), and eligible for salvation (Mccoy, Corduan \& Stoker 2016:4). Among modern Muslims like Jamal al-Banna, Mahmut Aydin, Abdulaziz Sachedina, Asghar Ali Engineer, Reza Shah-Kazemi, Sohail H. Hashim, Farid Esack and Abdou Filali-Ansary (Ibrahim 2014:444; Sirry 2012:424), pluralism is also well justified and parallel with Islamic theology and religious philosophy (Bakar 2010:12; Kamali 2011:33). The only difference is the path that leads to the goal. Recognition of the existence of various religions including Buddhism based on the concept of religious pluralism is enshrined in the teachings of the Qur'an (5:48) (Yusuf 2007:322). According to Kamali (2011:28), the purpose of religious pluralism is not just to be tolerant of others, but rather to take the initiative to understand others. Through the paradigm of religious pluralism, Muslims will appreciate the nature of diversity by promoting unity, cooperation, dialogue and understanding among believers.

\section{Conclusion}

Based on the discussion it can be summarised that Muslims have a certain view in the context of their relationship with Buddhists based on theological and philosophical encounters and the discussion of Muslim scholars on specific terms in the Islamic sources. Although there are significant differences between the two religions, Muslims use different approaches in approaching the Buddhist, whether within the framework of theology and philosophy.

\section{Acknowledgements Competing interests}

The authors declare that they have no financial or personal relationships that may have inappropriately influenced them in writing this article.

\section{Authors' contributions}

The research was carried out by A.F.R. under the supervision of Associate Prof. Dr. J.A. and Dr. Z.A.R.

\section{Ethical considerations}

This article followed all ethical standards for research without direct contact with human or animal subjects.

\section{Funding information}

This research received no specific grant from any funding agency in the public, commercial or not-for-profit sectors.

\section{Data availability}

Data sharing is not applicable to this article as no new data were created or analysed in this study.

\section{Disclaimer}

The views and opinions expressed in this article are those of the authors and do not necessarily reflect the official policy or position of any affiliated agency of the authors.

\section{References}

Abdullah, A.M.S., 2007, Al-Hiwar al-Dini al-Ibrahimi fi Mizan al-Quran, Dar al-Salam, Misr.

Ahmed, E.-W., 2019, "'Whoever harms a dhimmī I shall be his foe on the day of judgment": An investigation into an authentic prophetic tradition and its origins from the covenants', Religions, 10(9), 516. https://doi.org/10.3390/rel10090516

Alhashmi, M., Bakali, N. \& Baroud, R., 2020, 'Tolerance in UAE Islamic education textbooks', Religions 11(8), 1-13. https://doi.org/10.3390/rel11080377

Ali, M.B., 2018, Inclusivism and religious plurality: A Quranic perspective (RSIS Commentaries, No. 039), RSIS Commentaries, Nanyang Technological University.

Al-Maqdīsī, M.I.T., 2004, Kitāb al-Bad' wa al-Tārīkh, Maktabah al-Thaqafah al-Diniyyah,

Al-Shahrastani, Abi al-Fath Muhammad ibn `Abd al-Karīm., 1992, al-Milal wa al-Nihal, Dar al-Kutub al-'Ilmiyyah, Beirut.

Al-Qasimi, M.A.-D.J., 2002, 'Tafsir al-Qasimi al-Musamma Mahasin al-Ta'wil', Dar alKutub al-'Ilmiyyah, Beirut.

Asadu, G.C., Diara, B.C. \& Asogwa, N., 2020, 'Religious pluralism and its implications for church development', HTS Teologiese Studies/Theological Studies, 76(3), 1-9. https://doi.org/10.4102/hts.v76i3.5955

Azhar, M., Hamid, A., Yusuff, R., Othman, M.F. \& Balwi, M.K., 2013, 'Perspektif Orang Cina Terhadap Agama Islam di Malaysia: Satu Tinjauan', Jurnal Teknologi 60(1) 11-19. https://doi.org/10.11113/jt.v60.1443

Bakar, I.A., 2013, 'The religious tolerance in Malaysia: An exposition', Advances in Natural and Applied Sciences 7(1), 90-97.

Bakar, O., 2010, 'Cultural pluralism in a globalised world: Challenges to peacefu coexistence', Islam and Civilisational Renewal 1(3), 528-531.

Bakar, O., 2012, 'The Qur'ānic identity of the Muslim ummah: Tawhidic epistemology as its foundation and sustainer', Islam and Civilisational Renewal 3(3), 438-454.

Basri, G., 2009, 'Penghantar IImu Perbandingan Agama', Kolej Universiti Perguruan Ugama Seri Begawan, Bandar Seri Begawan.

Beckwith, C.I., 1979, 'The introduction of Greek medicine into Tibet in the seventh and eighth centuries', Journal of the American Oriental Society 99(2), 297. https:// doi.org/10.2307/602665

Berzin, A., 1994. Islamic-Buddhist dialogue, viewed 13 September 2017, from https:// studybuddhism.com/en/advanced-studies/history-culture/buddhism-islam/ islamic-buddhist-dialogue.

Çakmak, M., 2016, 'Foundations of religious inclusiveness in Muslim thought', Islamic Quarterly 60(4), 467-508.

Cheetham, D., Pratt, D. \& Thomas, D. (eds.), 2013, 'Religion and religious other', in Understanding interreligious relations, pp. 15-36, Oxford University Press, Oxford.

Çoruh, H., 2012, 'Friendship between Muslims and the people of the book in the Qur'an with special reference to Q 5.51', Islam and Christian-Muslim Relations 23(4), 505-513. https://doi.org/10.1080/09596410.2012.712436

Crouch, M., 2016, 'Personal law and colonial legacy state - Religion relations and Islamic law in Myanmar', Islam and the State in Myanmar: Muslim- Buddhist Relations and the Politics of Belonging 6(3), 45-66.

Elverskog, J., 2010, Buddhism and Islam on the Silk Road, University of Pennsylvania Press, Philadelphia, PA.

Ghazali, A.M., 2016, 'Toleransi Beragama dan Kerukunan dalam Perspektif Islam', Religious: Jurnal Agama dan Lintas Budaya, 1(1), 25-40.

Gravers, M., 2015, 'Anti-Muslim Buddhist nationalism in Burma and Sri Lanka: Religious violence and globalized imaginaries of endangered identities', Contemporary Buddhism 16(1), 1-27. https://doi.org/10.1080/14639947.2012.6 69278

Habibi, M.M., 2017, 'Corak pendidikan islam inklusif', eL-Tarbawi X(1), 35-48.

Hamid 'Abd al-Qadir, 1957, Buddha al-Akbar: Hayatuh wa Falsafatuh, Kaherah, Maktabah Nahdah Misr.

Hanafi, I., 2017, 'Eksklusivisme, Inklusivisme, dan Pluralisme: Membaca Pola Keberagamaan Umat Beriman', Al-Fikra: Jurnal IImiah Keislaman 10(2), 3848. https://doi.org/10.24014/af.v10i2.3848

Hassan, M.H., 2009, 'Interpreting Islam and plural society', Islam and Civilisational Renewal 1(1), 99-120. https://doi.org/10.52282/icr.v1i1.15

Hilmi, M., 1990, Al-Islam wa al-Adyan: Dirasah Muqaranah, Dar al-Da'wah, alIskandariyyah.

Hosein, I.N., 1976, Islam and Buddhism in the modern world, World Federation of Islamic Missions, Karachi.

Hussain, L.K.A.-S. \& Ramli, A.F., 2017, 'Contributions of Islamic Civilization to The Mathematics Development', Wawasan: Jurnal Ilmiah Agama dan Sosial Budaya 2(2), 199-208. https://doi.org/10.15575/jw.v2i2.1450 
Ibrahim, A., 2014, 'Denial, trivialization and relegation of pluralism: The challenges of managing diversity in multi-religious Malaysia and Indonesia', Studia Islamika 19(3), 355. https://doi.org/10.15408/sdi.v19i3.355

Jome, S.M.E., Ganjvar, M. \& Sarmadi, N.A., 2020, 'Faith in god, philanthropy and foundations of criticism of religious violence in mulla sadra's philosophy', HTS Teologiese Studies/Theological Studies 76(1), 1-8. https://doi.org/10.4102/hts. v76i1.6046

Kamali, M.H., 2011, 'Diversity and pluralism: A Quranic perspective', Pluto Journals 1, $27-54$

Khambali, H.K.M., Sintang, S. \& Rahman, N.F.A., 2019, 'Pemaknaan Semula Toleransi Agama Dalam Berta'amul', in A. Baharuddin, E.A. Aziz \& M.A. Kamarulzaidi (eds.) Islam dan Hubungan antara Penganut Agama, pp. 121-148, Penerbit Institut Kefahaman Islam Malaysia (IKM), Kuala Lumpur.

Klinken, G.V. \& Aung, S.M.T., 2017, 'The contentious politics of anti-Muslim scapegoating in Myanmar', Journal of Contemporary Asia 47(3), 353-375. https:// doi.org/10.1080/00472336.2017.1293133

Kroesbergen, H., 2020, 'Religious diversity, ecology and grammar', HTS Teologiese Studies/Theological Studies 76(1), 1-11. https://doi.org/10.4102/hts.v76i1.6064

Maclean, D.N., 1993, Religion and society in Arab Sind, vol. 52, E. J. Brill, Netherlands. Mccoy, D., Corduan, W. \& Stoker, H., 2016, 'Christian and Buddhist approach to
religious exclusivity: Do interfaith scholars have it right?', HTS Teologiese Studies/ Theological Studies 72(3), 1-8. https://doi.org/10.4102/hts.v72i3.3266

Obuse, K., 2010, 'The Muslim doctrine of prophethood in the context of BuddhistMuslim relations in Japan: Is the Buddha a prophet?', Muslim World 100(2-3) 215-232. https://doi.org/10.1111/j.1478-1913.2010.01314.x

Obuse, K., 2015, 'What does Bamiyan tell us about Muslim attitudes to Buddhism? unpacking "Buddhist-Muslim conflicts" in Contemporary Asia', Religions of South Asia 8(3), 301-320. https://doi.org/10.1558/rosa.v8i3.20234

Osman, M.N., 2017, 'Understanding Islamophobia in Asia: The cases of Myanmar and Malaysia', Islamophobia Studies Journal 4(1), 17-36. https://doi.org/10.13169/ islastudj.4.1.0017

Osman, M.N., 2019, 'The confluence of race and religion in understanding Islamophobia in Malaysia', in E. Bayrakli \& F. Hafez (eds.), Islamophobia in Muslim majority societies, pp. 161-174, Routledge, Oxon. https://doi.org/10.4324/9780429464850

Qomaruzzaman, B. \& Busro, B., 2019, 'Tolerance Islam theology of education hermeneutic reading of Tariq Ramadan thought' QIJIS (Qudus International Journal of Islamic Studies) 7(2), 203. https://doi.org/10.21043/qijis.v7i2.5128

Rahman, N.F.A. \& Khambali, K.M. @ Hambali, 2013, 'Religious tolerance in Malaysia: Problems and challenges', International Journal of Islamic Thought 3, 81-91. https://doi.org/10.24035/ijit.03.2013.007

Rahmat, O.K., 1984, Dari Adam sampai Muhammad: Sebuah Kajian Mengenai Agama-agama, Pustaka Aman Press, Kota Baharu.

Ramli, A.F. \& Awang, J., 2016, 'Dialog Antara Agama Menurut Perspektif Islam', International Journal of Islamic and Civilizational Studies 3(2), 22-34.

Ramli, A.F., Awang, J. \& Rahman, Z.A., 2018, 'Muslim scholar's discourse on Buddhism: A literature on Buddha's position', in International conference on humanities and social sciences (ICHSS 2018), vol. 53, pp. 1-11, EDP Sciences. https://doi. org/10.1051/shsconf/20185304001

Ramli, A.F., Awang, J. \& Rahman, Z.A., 2020a, 'Buddhism according to Modern Muslim Exegetes', International Journal of Islam in Asia 1(1), 49-66. https://doi. org/10.1163/25899996-01010004

Ramli, A.F., Awang, J. \& Rahman, Z.A., 2020b, 'Identifying Islamophobia in Malaysian Buddhist context', Al-Itqan: Journal of Islamic Sciences and Comparative Studies 5(2), 85-108.

Reis Habito, M., 2010, 'The notion of Buddha-nature: An approach to BuddhistMuslim dialogue', Muslim World 100(2-3), 233-246. https://doi. org/10.1111/j.1478-1913.2010.01321.x

Reza Shah-Kazemi, 2010, Common ground between Islam and Buddhism, Fons Vitae Louisville, KY.

Runzo, J., 2010, 'Pluralism and relativism', in C. Meister (ed.), The Oxford handbook of religious diversity, pp. 1-18, Oxford University Press, Oxford.

Sadiqi, H., 2008, 'Hiwar al-Hadharat bilawhar wa Budhasaf', Ahl Al-Bait Jurnal 1(8), 240-221.

Safehian, M., 2013, 'Salvation and redemption in the exclusivist and inclusivist views and Islamic thought', International Research Journal of Applied and Basic Sciences 4(12), 3863-3869.

Schmidt-Leukel, P., 2010, 'Buddhist-Muslim dialogue: Observations and suggestions from a Christian perspective', Muslim World 100(2-3), 349-363. https://doi. org/10.1111/j.1478-1913.2010.01317.x
Schmidt-Leukel, P., 2017, Religious pluralism and interreligious dialogue, Orbis Books, New York, NY.

Selim, M., 2011, 'The premises and promises of the Buddhist-Muslim dialogue', Journal of Oriental Studies 21(I), 178-188.

Sharma, S., Ghafoor, S. \& Gogineni, R.R., 2019, 'Symbols and identity in Islamophobia', in H.S. Moffic, J. Peteet, A.Z. Hankir \& R. Awaad (eds.), Islamophobia and psychiatry, pp. 95-100, Springer, Cham.

Sirry, M., 2009, 'Compete with one another in good works: Exegesis of Qur'an Verse 5.48 and contemporary Muslim discourses on religious pluralism', Islam and Christian-Muslim Relations 20(4), 423-438. https://doi.org/10.1080/ 09596410903194886

Sirry, M.A., 2012, 'Reformist Muslim approaches to the polemics of the Qur'ân against other religions', PhD thesis, The University of Chicago, Chicago, IL.

Sivarasa, S. \& Muzaffar, C., 1999, Alternative politics for Asia: A Buddhist-Muslim dialogue, International Movement for a Just World, Kuala Lumpur.

Smith, W.C., 1981, Towards a world theology, Westminster, Philadelphia, PA

Soka Gakkai Malaysia (SGM), 2014, SGM Perak co-organises mid-autumn lantern festival, viewed 13 September 2017, from http://www.sgm.org.my/en/index.php?cur=news/ view\&id=366\&title=SGM_Perak_Co-organises_Mid-Autumn_Lantern_Festival.

Stewart, J.J., 2014, 'Muslim-Buddhist conflict in contemporary Sri Lanka', South Asia Research 34(3), 241-260. https://doi.org/10.1177/0262728014549134

Syalaby, A., 2000, Adyan al-Hind al-Kubra: Al-Hindusiyyah, al-Jainiyyah, al-Buziyyah, 11th edn., Maktabah al-Nahdhah al-Misriyyah, Kaherah.

Tabataba'i, S.M.H., 1997, Al-Mīzān fi Tafsïr al-Qur'ān, Mu'assasah al-cAlami li Matbucah, Beirut.

Tabrizi, T.G., 2012, 'Ritual purity and Buddhists in modern Twelver Shi'a exegesis and law', Journal of Shi'a Islamic Studies 5(4), 455-471. https://doi.org/10.1353/isl.2012.0058

Tasman, T., 2017, 'Islam Inklusif: Konstruksi Pemikiran untuk Dialog Umat beragama di Indonesia', Dakwah: Jurnal Kajian Dakwah dan Kemasyarakatan 21(1), 132-146. https://doi.org/10.15408/dakwah.v21i1.11814

The Star, 2018, 'Let's Read the Quran', Campaign will be back in March, viewed 20 December 2020, from https://www.thestar.com.my/news/nation/2018/02/21/ lets-read-the-quran-campaign-will-be-back-in-march.

Thiselton, A., 2008, Approaching philosophy of religion: An introduction to key thinkers, concepts, methods \& debates, InterVarsity Press: Downers Grove, IL.

Van Eck, E., 2009, 'A prophet of old: Jesus the "public theologian"', HTS Teologiese Studies/Theological Studies 66(1), a771, 10 pages. https://doi.org/10.4102/hts. v66i1.771

Vaziri, M., 2012, Buddhism in Iran: An anthropological approach to traces and influences, Palgrave Macmillan, New York, NY.

Vidyarthi, M.A.H., 2020, 'Muhammad in World Scriptures: Buddha foretells advent of Prophet Muhammad', Ahmadiyya Anjuman Lahore Publications, Wembley.

Wahyudi, J., 1997, 'Ahl al-Kitab in the Quran: An analysis of selected classical and modem exegesis', PhD thesis, McGill University.

Yoeli-Tlalim, R., 2016, 'Islam and Tibet: Cultural interactions - An introduction', in A. Akasoy, C. Burnett \& R. Yoeli-Tlalim (eds.), Islam and Tibet: Interactions along the Musk Routes, pp. 1-16, Ashgate Publishing, Surrey.

Yong, H.H., Hamann, S.L., Borland, R., Fong, G.T. \& Omar, M., 2009, 'Adult smokers' perception of the role of religion and religious leadership on smoking and association with quitting: A comparison between Thai Buddhists and Malaysian Muslims', Social Science and Medicine 69(7), 1025-1031. https://doi. org/10.1016/j.socscimed.2009.07.042

Yusoff Ismail, M., 2010, 'Buddhism in a Muslim state: Theravada practices and religious life in Kelantan', Muslim World 100(2-3), 321-336. https://doi. org/10.1111/j.1478-1913.2010.01323.x

Yusuf, H., 2010a, 'Buddha in the Quran': Common ground between Islam and Buddhism, pp. 113-136, Fons Vitae, Louisville, KY.

Yusuf, I., 2003, 'Religious diversity in a Buddhist majority country: The case of Islam in Thailand', International Journal of Buddhist Thought and Culture 3, 131-143.

Yusuf, I., 2007, 'The Southern Thailand Conflict and the Muslim World', Journal of Muslim Minority Affairs 27(2), 319-339.

Yusuf, I., 2010b, 'Islam and Buddhism relations from Balkh to Bangkok and Tokyo', Muslim World 100(2-3), 177-186. https://doi.org/10.1111/j.1478-1913.2010.01312.x

Yusuf, I., 2013, 'Islam and Buddhism', in C. Cornille (ed.), The Wiley-Blackwell companion to inter-religious dialogue, pp. 360-375, Wiley-Blackwell, Malden, MA.

Yusuf, I., 2018, 'Three faces of the Rohingya crisis: Religious nationalism, Asian Islamophobia and delegitimizing citizenship', Studia Islamika: Indonesian Journa for Islamic Studies 25(3), 503-541. https://doi.org/10.15408/sdi.v25i3.8038 